\title{
The role of energy support schemes in renewable energy market penetration
}

\author{
Matti Lehtovaara $^{1}$, Matti Karvonen ${ }^{2}$, Tuomo Kässi ${ }^{1}$ \\ ${ }^{1}$ LUT School of Industrial Engineering and Management, Lappeenranta University of Technology, P. O. Box 20, Lappeenranta, Finland \\ ${ }^{2}$ LUT School of Industrial Engineering and Management, Technology Business Research Center, Lappeenranta University of Technology, \\ P. O. Box 20, Lappeenranta, Finland
}

Email address:

matti.lehtovaara@lut.fi (M. Lehtovaara), matti.karvonen@lut.fi (M. Karvonen), tuomo.kassi@lut.fi (T. Kässi)

To cite this article:

Matti Lehtovaara, Matti Karvonen, Tuomo Kässi. The Role of Energy Support Schemes in Renewable Energy Market Penetration, International Journal of Renewable and Sustainable Energy. Vol. 2, No. 2, 2013, pp. 30-40. doi: 10.11648/j.ijrse.20130202.12

\begin{abstract}
A wide consensus exists about climate change due to the use of fossil fuels. Energy efficiency, decreased use of fossil fuels, and wide diffusion of renewable energy are vital for limiting global warming. The objective of this study is to analyze how wind power and distributed bio-energy could be commercialized effectively. The evaluation is based on a case study, literature reviews and semi-structured interviews of energy experts. The results demonstrate that renewable energy is not yet competitive against fossil-fuel energy without political support schemes during the next decades. The research reveals that novel ecosystems require commercial support in their early lifecycle.
\end{abstract}

Keywords: Energy Subsidies, Wind Power, Bio-Energy, Commercialization, Climate Change

\section{Introduction}

The threat of global warming and climate change, the diffusion of renewable energy, and the question of how to make the long transition to an economy based on fossil-fuel alternatives are concerns for most societies [1]. There exists a wide mutual understanding that climate is changing universally, mostly due to increasing greenhouse gases in the atmosphere as a result of the increased use of fossil fuels. The surface temperature of the Earth could rise significantly during the next few decades, resulting in such impacts that we would witness an entirely new planet unknown to us [2]. However, improving energy efficiency, decreasing the use of fossil fuels, and wide diffusion of various renewable energy sources are among the most vital actions in limiting global warming to a sustainable level [3].

The central scenario [4] is somewhat more pessimistic, as it predicts that even the new policies will lead to emissions that correspond to a global temperature increase of about $3.6{ }^{\circ} \mathrm{C}$ this century, far above the sustainable $2{ }^{\circ} \mathrm{C}$. Shell [5] confirms that the driver at economic growth, especially in developing economies, largely neglects the environmental agenda. Although a more sustainable pathway is possible, it will be extremely challenging to implement [5]. However, the climate change issue can be solved in such a manner that global warming can be limited to sustainable two degrees.
There are enormous resources of wind energy globally to be harnessed into energy production, and biomass utilization can also be increased significantly. The overall energy efficiency could be improved e.g. by using smart grids, novel energy storage systems, and electric vehicles. Technological solutions exist for solving many of the problems, and sustainable solutions can most certainly be invented for the rest. The biggest hindrances to preventing the development seem to be human behavior and the desire to increase personal prosperity. In general, the reluctance of politicians to support the diffusion of renewable energy by a consistent long-term policy increases the challenge $[2,6]$.

As a matter of fact, a lot has already been done during the last decade. Global investments into renewable energy sources between 2004 and 2011 increased annually by about $30 \%$ on average, and reached USD 260 billion in 2011. The renewable energy included wind power, bio-energy, solar power, geothermal energy, and small hydro power [7]. The European Union (EU) has set binding renewable energy targets to source $20 \%$ of the Member States' total energy consumption from renewable energy sources (RES) in 2020. The majority of the increasing non-hydro renewable electricity production is expected to come from wind power and bio-energy, whereas bio-energy remains the dominant source of non-fossil heat $[8,9]$. Since the renewable energy potential differs from one Member State to another, the 
targets and promotion frameworks differ between the States [9]. Sweden has the highest renewable energy (RE) target: a $49 \%$ share of final energy consumption from RES in 2020, and Malta has the lowest RES target of $10 \%$ [8]. Climate and energy policies, and regulation in general, as well as long-term price-based instruments such as subsidies and in particular taxes, can significantly increase the innovation and diffusion of novel renewable technologies [10-12].

In this research, we use a case study research method to explore how the diffusion of wind power and distributed bio-CHP (combined heat and power production) could be efficiently promoted in Finland. Finland's RE diffusion performance is compared with two other European countries, Denmark and Germany, which have already promoted RE quite successfully. The focus of the study is on wind power and bio-energy, since these technologies are expected to contribute the biggest share of the increase of RES in Europe during the next decade $[8,9]$. The research methods include semi-structured interviews of energy experts from the industry, academics and state officials to find an answer to the research question: "How do energy subsidies and other support schemes influence the diffusion of wind power and distributed bio-CHP?" The results contribute to earlier research confirming that emerging renewable energy still needs price-based subsidies and other support instruments in order to compete successfully with other energy sources. The results reveal that predictable long-term support policies promote renewable energy innovations and diffusion more significantly than in countries where the implementation of support instruments is less dynamic. The paper is structured as follows: in section two we describe modern wind power and bio-CHP technologies and markets, section three discusses energy mix and support scheme issues especially within the EU, and the research methods are described in section four. The results of the study are analyzed in section five, and section six contains discussion and conclusion.

\section{Wind Power and Bio-Energy Tech- nologies and Markets}

According to [10-12], climate and energy policies, government regulation, and long-term subsidies and taxes can significantly increase the innovation and diffusion of novel renewable technologies. Hence, it can be judged that the emerging wind power and bio-energy technologies have benefited from various support schemes in their early lifecycle phases in terms of technological development and market diffusion.

\subsection{Wind Power}

The world's wind resources are enormous: according to estimates, utilising only one fifth of the economically viable global inland wind resources for power generation would have exceeded the world's electricity consumption in the year 2000 seven times over [13]. Studies by the European Environment Agency also claim that the technical potential of offshore wind in Europe is six to seven times greater than the predicted electricity demand in Europe in 2020 [14]. Wind kinetic energy was used to generate electricity for the first time over a century ago, but wind power is still in the emergent stage in its lifecycle $[15,16]$. According to [16], the reason for the slow diffusion is the lack of a societal crisis that often drives to radical innovation, and only the oil shocks in the 1970s finally accelerated wind power innovation and investments.

The typical design of a modern wind turbine is the horizontal axis wind turbine (HAWT) with the rotation axis parallell to the ground. The key components of a HAWT include a rotor (containing a hub and typically two or three blades), a nacelle (including a generator, the main frame, a drive train containing rotating parts, such as the main shaft and possibly a gearbox, and control and electrical systems), and a tower and foundation. During the past decades, the nominal power of wind turbines has grown notably, and today the biggest operational turbines are 7.5 MW in size. Wind turbines with a power rating of $10 \mathrm{MW}$ and beyond are under design [17-19].

The global installed cumulative wind power capacity was over $240 \mathrm{GW}$ in 2011, consisting mostly of onshore installations. The cumulative market is predicted to reach $900 \mathrm{GW}$ by 2020 . The biggest cumulative markets in 2011 were China and the USA, followed by Germany and Spain. The biggest wind turbine manufacturer in 2011 was Danish Vestas with sales of almost six billion euros. Among the top ten turbine manufacturers were four Chinese firms that had grown rapidly, as had the Chinese market [19].

\subsection{Bio-Energy}

In this paper, the focus is on distributed combined heat and power production (CHP) that uses biomasses, such as woodchips from logging residue. The technologies for commercial small-scale CHP production are mostly based on combustion technologies. A bio-fuelled CHP-plant consists of a boiler, firing unit, turbine, bio-fuel storage and conveyor, as well as automation [20]. The principle of combined heat and power production has been known for a long time, and since the beginning of the $20^{\text {th }}$ century a number of units have been in operation. However, commercial small-scale CHP technologies are still under development today. CHP contains the following essential elements: simultaneous heat and electricity production, high-efficiency performance, and proximity of the energy production unit to the customers [21].

Potential customers for distributed bio-CHP technology using forest biomasses include farms, greenhouses, small and medium size enterprises, real estate outside urban areas, and district heating plants. These actors may operate fairly independently or cooperate actively e.g. in joint forest biomass harvesting, transportation and refining to wood chips. Further, they may also collaborate with various service providers, such as maintenance firms and plant and component manufacturers [22].

All in all, bio-energy accounted for about $10 \%$ of the 
world's primary energy consumption in 2010 . The potential use of bio-energy could be almost doubled, accounting for about $15 \%$ of the world's energy demand in 2035, provided that the 450 scenario of the International Energy Agency can be implemented. However, the 450 scenario requires fast adoption of policies leading the world to a sustainable pathway limiting the global warming to two degrees, and this scenario can be regarded as rather challenging [4].

\section{Energy Mix, Support Schemes and Subsidies in the EU}

\subsection{Energy Mix}

In the EU 27 countries, the share of RES from gross final energy consumption was $11.7 \%$ in 2009. In Finland the share of RES was $30.3 \%$, in Denmark $19.9 \%$, and in Germany $9.8 \%$ in 2009. The RES targets from total energy consumption are 20,38, 30, and $18 \%$, respectively, in 2020 . The EU countries' own primary energy production consisted of fossil fuels (53.3\%), nuclear energy (28.4\%), and RES (18.3\%). Finland's own production was divided to fossil fuels (15.1\%), nuclear energy (37.1\%), and RES (47.8\%). Denmark's production was spread to fossil fuels $(88.5 \%)$, and RES (11.5\%), and Germany produced $51 \%$ from fossil fuels, $27.3 \%$ from nuclear energy, and the share of RES was $21.7 \%$ in 2009 [23].

The production and consumption of RES in the EU has increased significantly from $5.6 \%$ of the gross final consumption in 2000 to $12.5 \%$ in 2010 . Finland's the total share of RES was $32.2 \%$ in 2010. In Finland the share of bio-energy has been quite constant, $21.9 \%$ in 2010 . This is mainly due to the bio-CHP production in pulp and paper industry and in large district heating units. The share of wind power was $0.1 \%$ in 2010. In Denmark the share of RES was $9.8 \%$ in 2000 and $22.2 \%$ in 2010. Both bio-energy and wind power had increased by about two-fold. In Germany the share of RES was $3.9 \%$ in 2000 and $11 \%$ in 2010. The use of bio-energy had increased by about six-fold, and wind power by over four-fold. Fig. I depicts the development in the selected countries and the targets in 2020 [24-27].

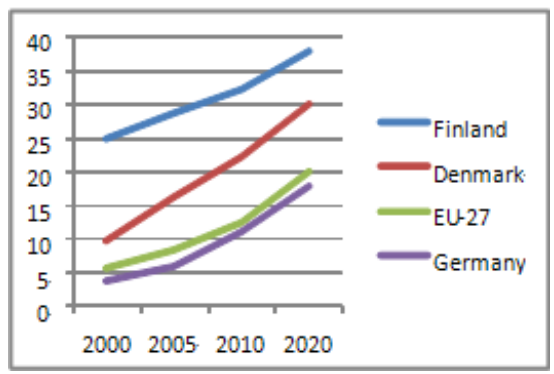

Figure 1. RES-\% of the total energy consumption 2000-2010 and targets 2020.

As a comparison, the primary energy demand in the world consisted of fossil fuels ( $81 \%$ ), nuclear energy (5.7\%), and RES $(13.3 \%)$ in 2010 . The world's energy mix has not changed in the $21^{\text {st }}$ century: in 2000 the share of fossil fuels was $80.3 \%$, followed by RES (13\%), and nuclear energy $(6.7 \%)$ [4].

\subsection{Energy Support Schemes}

According to [28], there has long existed an array of energy support schemes and subsidies. Some of the support schemes implemented by different nations are more transparent than others. [29] provides Country Attractiveness Indices (CAI) for renewable energy worldwide. The renewable index assessment includes wind and solar power, and biomass and other resources (geothermal, small hydro, wave and tidal technologies and landfill gas). The assessment takes the following infrastructure issues into account: electricity market regulation, planning environmental and grid connection issues, and the energy financing environment. Further, each technology is assessed by considering the following on a weighted basis:

Attractiveness of power off-take - including the price received, the variation and length of the power purchase agreement, and government guarantees for power off-take

Taxation climate - incentives to promote green energy, penalties to brown (fossil fuel) energy

Soft loans - national or international loans to promote novel renewable technologies

Market growth potential - current capacity compared to published targets, and policy frameworks that support growth

Current installation base - high penetration demonstrates established infrastructure, and potential to repowering older plants

Others: resource quality, e.g. average wind speeds and project size, large projects suggesting a favourable environment and economies of scale

The assessment showed that after China and the USA, Germany received the highest score. Of the EU countries Italy was the fifth followed by the UK and France. Sweden was $10^{\text {th }}$, Denmark $19^{\text {th }}$ and Finland $26^{\text {th }}$.

The studies of [30] show that instruments such as efficient innovation systems are similarly important in the diffusion of novel technology. In Denmark, for example, different wind power actors gradually formed a well-functioning innovation system that created a platform for the success of the Danish wind power industry through innovation programs, combined resources and accumulated knowledge.

EU has defined a clear set of objectives to mitigate the climate change issues. The future energy policy of the EU is based on five pillars: increased energy efficiency, saving $20 \%$ of the energy consumed by 2020; increasing the use of renewable energy to $20 \%$ by 2020 ; raising the share of clean hydrocarbons that are consumed e.g. through the capture and storage of carbon dioxide (CCS); extending the carbon market in the EU that today covers about half of the emissions; and finally, continuing to influence the mitigation of global warming internationally [31].

The European Commission [32] expresses its satisfaction to the fast deployment of renewable energy in Europe during 
the past years, driven by technology improvements, economies of scale, and the Member States' support schemes. However, there are several challenges in the energy policy of the EU that need to be addressed especially in the present economic circumstances, when investors are cautious to invest into capital-intensive energy markets such as policy-dependent renewable energy. First, the future renewable energy framework should be certain and predictable also beyond 2020. Second, the financial incentives should have long-term viability. Third, the market arrangements in the EU have to be consistent. Fourth, the energy infrastructure i.e. the existing power grid has to be upgraded to be adequate to serve the increasing proportion of decentralised and intermittent power production. Fifth, diffusion of the emerging renewable energy technologies has to be promoted. Finally, in spite of the generally widespread public acceptance of RE, potential barriers to future growth have to be dealt with, ensuring the acceptance and sustainability of renewable energy. Table 1 illustrates the future support scheme challenges in the energy policy of the EU in detail [32].

Table 1. Future support scheme challenges in the energy policy of the EU.

\begin{tabular}{|c|c|}
\hline The six challenges & Description \\
\hline $\begin{array}{l}\text { Future policy } \\
\text { framework }\end{array}$ & $\begin{array}{l}\text { The current energy policy framework } \\
\text { ends in } 2020 \text {. Binding renewable } \\
\text { energy objectives beyond } 2020 \text { have } \\
\text { to be decided on. }\end{array}$ \\
\hline $\begin{array}{l}\text { Viability of financial } \\
\text { incentives }\end{array}$ & $\begin{array}{l}\text { Member States' different support } \\
\text { schemes should be unified and the } \\
\text { financing should have long-term } \\
\text { viability. }\end{array}$ \\
\hline $\begin{array}{l}\text { Consistent market } \\
\text { arrangements }\end{array}$ & $\begin{array}{l}\text { The internal market arrangements } \\
\text { should be consistent in order to avoid } \\
\text { inefficiencies in investments and } \\
\text { market operations. }\end{array}$ \\
\hline $\begin{array}{l}\text { Adequate energy } \\
\text { infrastructure }\end{array}$ & $\begin{array}{l}\text { The existing grid has to be upgraded } \\
\text { in order to meet the requirements of } \\
\text { the increasing proportion } \\
\text { of decentralized and } \\
\text { intermittent renewable electricity } \\
\text { production. }\end{array}$ \\
\hline $\begin{array}{l}\text { Uncertainty of future } \\
\text { technologies }\end{array}$ & $\begin{array}{l}\text { Novel technologies are needed to } \\
\text { achieve the transition to sustainable } \\
\text { energy, and these } \\
\text { challenging modern } \\
\text { ecosystems cannot be achieved by } \\
\text { market mechanisms alone. }\end{array}$ \\
\hline $\begin{array}{l}\text { Sustainability and public } \\
\text { acceptance }\end{array}$ & $\begin{array}{l}\text { Today, renewable energy is widely } \\
\text { accepted by the public. In the future, } \\
\text { the potential concerns about } \\
\text { e.g. land-use and } \\
\text { other environmental issues } \\
\text { of large-scale renewable } \\
\text { energy projects have to be solved. }\end{array}$ \\
\hline
\end{tabular}

\subsection{Energy Subsidies}

Governments have long used various types of energy subsidies to promote their energy policies. When subsidies to renewable energy sources and low-carbon energy technologies are well planned, they can achieve long-term en- vironmental and economic benefits. However, fossil fuels are also subsidised in many countries, and this phenomenon tends to outweigh the benefits [28]. It is predicted that in spite of the growth of renewable and low-carbon technologies, fossil fuels will maintain their dominant position in the world's energy mix for the next decades. Fossil fuels were subsidised about six times more than RES, amounting to USD 523 billion in 2011, an almost $30 \%$ growth from the previous year. Fossil fuel subsidies are more prevalent in developing countries than industrialised countries [4]. A common justification for fossil fuel subsidies is that they help the poorest people to get access to electricity, since 1.3 billion people still lack the access and 2.7 billion have unclean cooking facilities [28]. However, the results of the use of fossil fuel subsidies are contradictory, and due to various barriers the poorest people do not necessary gain access to electricity [28, 33]. In a global survey, fossil-fuel subsidies were identified in 37 countries, and $40 \%$ of those economies have already taken actions to abandon these subsidies. In case further actions are not taken, fossil-fuel subsidies are predicted to reach USD 660 billion in 2020 . Renewable energy subsidies, on the other hand, were USD 66 billion in 2010 and they are expected to reach USD 250 billion in 2035 [28].

Common mechanisms for renewable energy subsidies include e.g. tariffs, premiums, quotas, tax reductions, and low-interest loans. The most common ones are feed-in tariffs (FIT) and premiums that grant producers a certain price for the electricity they feed into the grid. Some states have quota obligations that oblige consumers to buy a proportion of their electricity produced by RE. In some countries tax reductions and low-interest loans are granted to producers that generate electricity into the grid from RES [28, 8]. Energy subsidies such as FITs seem to promote the diffusion of RE in different countries effectively, provided that they are well-planned and efficiently implemented [34-38]. However, although renewable energy support schemes tend to encourage the diffusion of RE, subsidies may create contradictory impacts to consumers, since in many cases the public support schemes are financed by increasing the final consumer prices [39]. Jefferson [40] complies with this and adds that although a lot has been done to promote RE, fossil fuels still account for about $80 \%$ of the world's energy mix. Jefferson criticises that the energy subsidies are often inefficient, and directed to mature RES that should already manage without them. Instead, among other things, research, investments and subsidies should be directed to less mature RES in order to accelerate the transition to RE [40].

In the EU, about ten thousand power plants and factories participate in the emission trading scheme (ETS) that aims to reduce the $\mathrm{CO}_{2}$ consumption by defining a price for emissions. The emission trading promotes the transition from fossil fuels to renewable ones, and increases the competitiveness of renewable energy. The intent is to expand the global reach of the mechanism by trading the emission credits with industrialized countries using the Joint Implementation Mechanism with emission targets, and with 
developing countries through the non-binding Clean Development Mechanism [9]. According to [41], effective carbon pricing, i.e. sufficiently high carbon prices affect investment decisions, and flexible FITs will be key incentives to promote new renewable energy technologies and energy efficiency issues. In today's high economic uncertainty, the implementation of these instruments require considerable political will from the governments, however.

\subsection{Support policies in Finland, Denmark and Germany}

\subsubsection{Finland}

Finland's primary energy consumption was 34.0 million tonnes of oil equivalent (mtoe) in 2009 compared to 33.3 mtoe in 1999 [23]. Finland's environment and energy strategy from 2008 defines the target for RE as $38 \%$ of final energy consumption in 2020. The strategy became lawful in the beginning of 2011, and it contains new FITs and tax incentives that have already been in use [8, 42].

The feed-in tariff for electricity produced by wind power is $83.5 € / \mathrm{MWh}$ and valid for 12 years. However, a higher FIT of $105.3 € / \mathrm{MWh}$ can be paid to wind power operators up to three years before the end of 2015. The feed-in tariff is a premium mechanism meaning that the target price $(83.5 / 105.3 € / \mathrm{MWh})$ is paid to the operator, if the market price of electricity is lower than that. If the market price of electricity is higher, then no FIT is paid. The subsidies can be paid for wind power plants that are bigger than $500 \mathrm{~kW}$ in nominal power, supposed that the turbines have been accepted to the FIT mechanism before the total installed wind power capacity in Finland exceeds 2500 MW. Wind power plants that are not eligible for the FIT will receive a fixed premium of $6.9 € / \mathrm{MWh}[8,42]$.

Electricity and heat produced by bio-energy have different support mechanisms. Firstly, the harvesting costs of small-sized wood, logging residue, and stumps are currently too expensive. Thus, harvesting young forests or logging areas is subsidised by different schemes provided that the wood is used for energy purposes. Secondly, electricity produced from wood chips is supported by a premium that varies depending on the price of the carbon emission permits. In case the permit price is $10 € /$ ton or lower, the premium is $18 € / \mathrm{MWh}$. When the emission permit price rises over 23 $€ /$ ton, a premium is not paid. Thirdly, a wood fuel -powered CHP-plant with a nominal generator output of between 100 $\mathrm{kW}_{\mathrm{e}}$ to $8 \mathrm{MW}_{\mathrm{e}}$, is entitled to a FIT of $83.5 € / \mathrm{MWh}$, similar to the one of wind power FIT. The maximum annual FIT paid to any one bio-energy plant is limited to 0.75 MEUR. The first 50 wood fuel -powered plants with $150 \mathrm{MW}_{\mathrm{e}}$ total nominal generator power can be accepted to the support mechanism. The support mechanisms for bio-energy plants are also valid for 12 years $[8,42]$.

\subsubsection{Denmark}

Denmark's primary energy consumption was 19.4 mtoe in 2009 (20.3 mtoe in 1999) [23]. Denmark's target is that $30 \%$ of energy consumption will come from RES in 2020, and the country will become entirely independent of fossil fuels by
$2050[8,42,43]$.

Onshore turbines bigger than $25 \mathrm{~kW}$ in nominal power receive a production premium of $33.6 € / \mathrm{MWh}$ for the first 22 000 full load production hours (approx. 7-9 years) after their initial grid connection. In addition, there is a $3.1 € / \mathrm{MWh}$ compensation to cover grid balancing costs for wind-power electricity. Domestic wind turbines smaller than $25 \mathrm{~kW}$ receive a FIT worth $80.6 € / \mathrm{MWh}$ for the electricity they feed into the grid. Offshore turbines and wind parks are subsidized by production area-specific support mechanisms. The Danish Energy Agency announces tenders for specific, geographically defined offshore sites, and applicants quote prices and terms at which they are willing to produce electricity. The winning prices in terms of FIT thus vary from one offshore project to another $[8,42,43]$.

Electricity produced solely or partly by bio-energy is entitled to a production premium of $20.1 € / \mathrm{MWh}$. In addition, fossil fuels used for heating are rather heavily taxed, whereas heating by bio-energy is exempted from these taxes $[8$, 42].

\subsubsection{Germany}

Germany's primary energy consumption was 326.6 mtoe in 2009 (341.5 mtoe in 1999) [23]. Germany's RES target is $18 \%$ of the total energy consumption in 2020. Further, Germany aims to shut down all its nuclear power plants by 2022, invests remarkably in grid renewal and smart grids, and improves the energy efficiency. The Ministry for the Environment, Nature Conservation and Nuclear Safety has defined minimum tariffs for wind power and bio-energy that are valid for the commissioning year of the plant and 20 years thereafter [8, 42].

Onshore wind power is subsidised by a basic FIT of 48.7 $€ / \mathrm{MWh}$. An initial tariff of $89.3 € / \mathrm{MWh}$ is paid for the first five years after the commissioning of the power plant, and an additional $4.8 € / \mathrm{MWh}$ bonus is granted also for five years for turbines that have a grid connection before the end of 2015. These tariffs are valid and unchanged for power plants that are commissioned in 2012. The defined tariffs for the next years will decrease by $1.5 \%$ annually. The basic FIT for offshore wind power is $35 € / \mathrm{MWh}$, and a higher $150 € / \mathrm{MWh}$ initial tariff is paid for the first 12 years after the commissioning of the power plant. Alternatively, there is an accelerated model for the offshore wind power tariff of 190 $€ / M W h$ that is valid for 12 years. The normal and accelerated model can be extended in case a wind park is located beyond 12 nautical miles from the shore or in water depths over 20 meters. The tariffs are unchanged until 2018 and after that the tariffs for the new power plant investments will decrease by $7 \%$ annually $[8,44]$.

The tariffs for electricity generated by biomass differ depending on the size of the power plant. The FIT for bio-energy power plants smaller than $150 \mathrm{~kW}_{\mathrm{e}}$ (electricity production) is $143 € / \mathrm{MWh}$. Plants with nominal electricity output between 150 to $500 \mathrm{~kW}_{\mathrm{e}}$ are entitled to a $123 € / \mathrm{MWh}$ subsidy. Plants of $500 \mathrm{~kW}_{\mathrm{e}}$ to $5 \mathrm{MW}_{\mathrm{e}}$ are eligible for a 110 $€ / \mathrm{MWh}$ tariff, and CHP-plants from $5 \mathrm{MW}_{\mathrm{e}}$ to $20 \mathrm{MW}_{\mathrm{e}}$ are 
entitled for a $60 € / \mathrm{MWh}$ subsidy. The above tariffs are valid and unchanged for 20 years for power plants that are commissioned in 2012. The defined tariffs for the next years' power plant investments will decrease by $2 \%$ annually [ 8 ,
44].

The current focal energy subsidies for wind power and bio-energy in Finland, Denmark and Germany are summarized in table 2 .

Table 2. Current key subsidies for wind power and bio-energy in Finland, Denmark and Germany.

\begin{tabular}{|c|c|c|c|}
\hline & Finland & Denmark & Germany \\
\hline $\begin{array}{l}\text { Onshore } \\
\text { wind power }\end{array}$ & $\begin{array}{l}\text { FIT } 83.5 € / \mathrm{MWh} 105.3 \text { for } \\
\text { three years before } 2015 \\
\text { Turbines }<500 \mathrm{~kW} \\
\text { premium } 6.9 € / \mathrm{MWh} \\
\text { Duration } 12 \text { years } \\
\text { Mechanism ceases when } \\
\text { the total installed wind power } \\
\text { capacity exceeds } 2500 \mathrm{MW}\end{array}$ & $\begin{array}{l}\text { Premium } 33.6 € / \mathrm{MWh} \text { for the } \\
\text { first } 22000 \text { full-load production } \\
\text { hours }(7-9 \text { years), in addition } \\
3.1 € / \mathrm{MWh} \text { compensation } \\
\text { for grid balancing costs } \\
\text { Turbines }<25 \mathrm{~kW} \text {, } \\
\text { FIT } 80.6 € / \mathrm{MWh}\end{array}$ & $\begin{array}{l}\text { FIT } 48.7 € / \mathrm{MWh} \text {, initial FIT } 89.3 € / \mathrm{MWh} \\
\text { for the first five years } \\
\text { Bonus } 4.8 € / \mathrm{MWh} \text { for five years for tur- } \\
\text { bines commissioned before the end of } 2015 \\
\text { Duration } 20 \text { years } \\
\text { The } 2012 \text { tariffs will decrease by } \\
1.5 \% \text { a for new installations }\end{array}$ \\
\hline $\begin{array}{l}\text { Offshore } \\
\text { wind power }\end{array}$ & Same as for onshore wind power & $\begin{array}{l}\text { FIT through auction, } \\
\text { site-dependent }\end{array}$ & $\begin{array}{l}\text { FIT } 35 € / M W h \text {, initial FIT } 150 € / M W h \text { for } \\
\text { the first } 12 \text { years; Duration } 20 \text { years } \\
\text { Tariff unchanged until } 2018 \text {, thereafter } \\
\text { deduction by } 7 \% / \text { a } \\
\text { Alternatively accelerated model FIT } 190 \\
€ / \text { MWh, duration } 12 \text { years } \\
\text { The normal and accelerated model duration } \\
\text { will be extended if the site is beyond } 12 \\
\text { nautical miles from the shore or in water } \\
\text { depths over } 20 \text { meters }\end{array}$ \\
\hline Bio-energy & $\begin{array}{l}\text { Wood chip -powered CHP; } \\
\text { premium } 18 € / \mathrm{MWh} \text {, when the } \\
\text { carbon emission permit costs } \\
10 € / \text { ton, premium } 0 € / \mathrm{MWh} \text {, } \\
\text { when the permit costs } 23 € / \text { ton } \\
\text { Wood-powered CHP }\left(100 \mathrm{~kW}_{\mathrm{e}}-8 \mathrm{MW}_{\mathrm{e}}\right) \text {, } \\
\text { FIT } 83.5 € / \mathrm{MWh} \text {; valid for the } \\
\text { first } 50 \text { plants until } 150 \mathrm{MW}_{\mathrm{e}} \\
\text { total capacity is exceeded } \\
\text { Max. } 0.75 \mathrm{MEUR} / \mathrm{a} \text { subsidy } \\
\text { per plant } \\
\text { Duration } 12 \text { years } \\
\text { Energy wood harvesting } \\
\text { subsidies }\end{array}$ & $\begin{array}{l}\text { Premium } 20.1 € / \mathrm{MWh} \\
\text { Tax exemption }\end{array}$ & $\begin{array}{l}\text { Turbines }<150 \mathrm{~kW}_{\mathrm{e}}, \text { FIT } 143 € / \mathrm{MWh} \\
150-500 \mathrm{~kW}_{\mathrm{e}}, \text { FIT } 123 € / \mathrm{MWh} \\
500 \mathrm{~kW}_{\mathrm{e}}-5 \mathrm{MW}_{\mathrm{e}}, \text { FIT } 110 € / \mathrm{MWh} \\
5 \mathrm{MW}_{\mathrm{e}}-20 \mathrm{MW}_{\mathrm{e}}, \text { FIT } 60 € / \mathrm{MWh} \\
\text { Duration } 20 \text { years } \\
\text { The } 2012 \text { tariffs will decrease by } \\
2 \% / \mathrm{a} \text { for new installations }\end{array}$ \\
\hline
\end{tabular}

\section{Research Methods}

The empirical study was executed using the case study research method. Yin [45] defines a case study as a research method that investigates a contemporary phenomenon within its real world context. In general, a case study method is favored, when "why" or "how" research questions are proposed, the investigator has little control over events, and the focus is on contemporary events. On the other hand, [46] claims that actually a case study is not a methodology, but rather a research strategy that concentrates on increasing the understanding of present dynamics within a single setting. Case studies also typically combine diverse data collection methods, such as interviews, questionnaires, observations and archives. Creswell [47] determines a case study as an exploration of an exclusive system that can be defined in terms of time and place, and through detailed, in-depth data collection involving multiple and ample sources of information.

Yin [45] continues arguing that it is often essential to use multiple sources of evidence converging the data in a triangular fashion. This challenge is one of the ways that makes case study research "hard", although it has classically been regarded as a "soft" form of research. The most common sources of evidence include: interviews, documentation, archival records, direct or participant observation, and physical artifacts. Case studies may include both qualitative and quantitative data. Although case study is a distinctive research method, some scholars are concerned about the possible lack of scientific rigor that is related to an investigator's ability to execute solid case studies. Other limitations include the qualities that case studies may provide too little basis for generalization, and may be laborious to execute [45].

In this qualitative case study, the research methods consisted of literature reviews and semi-structured interviews. Altogether 11 energy experts from the wind power and bio-energy industry, academics and state officials were interviewed. The interviewees were two chief executive officers (CEO), professors, directors, senior researchers and managers, and of one chief technical officer (CTO). The study was conducted with a semi-structured theme questionnaire that concentrated on two main areas and the questions related to them: 
General energy development issues by 2030: energy use and price development in Finland, Europe and globally, including the main drivers; energy mix development; energy efficiency; influences of global warming; lobbying of different interest groups.

Renewable energy development issues by 2030: competitiveness of wind power and distributed bio-CHP; energy subsidies and emission-trading schemes, including political transparency and predictability; grid reinforcement and smart grid issues; standby power production capacity and electricity storage; citizens' acceptance and other issues; successful and unsuccessful examples from Europe and elsewhere.

The study was conducted in order to answer the research question: "How do energy subsidies and other support schemes influence the diffusion of wind power and distributed bio-CHP?" The focus of the study was in Finnish energy politics and markets in comparison with the policy and market developments in Denmark and Germany. General energy issues related to the leading energy consumers such as the USA, China, and India served as background information for the study. The long experience and extensive knowhow of the interviewees about the renewable energy industry, research and politics contributed to the results of the research significantly. The interviewees' position, organization and energy technology experience, as well as the duration of the interview are presented in table 3 .

Table 3. Interviewees and duration of the interview.

\begin{tabular}{lll}
\hline Interviewee & $\begin{array}{l}\text { Position, organization and energy } \\
\text { technology experience }\end{array}$ & $\begin{array}{l}\text { Interview } \\
\text { duration, } \\
\text { min. }\end{array}$ \\
\hline 1 & $\begin{array}{l}\text { Professor, energy technology, university, } \\
\text { over 20 years' experience }\end{array}$ & 60 \\
& $\begin{array}{l}\text { Manager, bio-energy firm, over 20 years' } \\
\text { experience }\end{array}$ & 50 \\
3 & $\begin{array}{l}\text { Director, ministry, over 20 years' experience } \\
\text { Entrepreneur, CTO, professor, bio-energy } \\
\text { firm, 40 years' experience }\end{array}$ & 60 \\
4 & $\begin{array}{l}\text { Manager, entrepreneur, interest group, } \\
\text { 30 years' experience }\end{array}$ & 75 \\
5 & $\begin{array}{l}\text { Senior researcher, state organization, } \\
\text { 20 years' experience }\end{array}$ & 60 \\
7 & $\begin{array}{l}\text { Senior researcher, research institute, } \\
9 \text { years' experience }\end{array}$ & 50 \\
8 & $\begin{array}{l}\text { CEO, wind power firm, 10 years' experience } \\
\text { Professor, energy technology, university, }\end{array}$ & 55 \\
9 & $\begin{array}{l}\text { over 20 years' experience } \\
\text { Director, state organization, over 10 } \\
\text { years' experience }\end{array}$ & 55 \\
10 & CEO, energy firm, over 20 years' experience & 65 \\
\hline 11 &
\end{tabular}

\section{Empirical Analysis}

The 11 experts responded to the general energy development theme with a global, European, and Finnish perspective in mind. The other main theme, renewable energy development issues were discussed more from the Finnish and European perspectives. It turned out that the inter- viewees had unified opinions in several issues, but opposite and revolutionary opinions also existed.

According to most specialists, energy consumption and especially electricity use will most probably increase remarkably globally during the next decades. The main drivers behind the development are population growth and gross domestic production (GDP) growth in many countries. One interviewee mentioned: "Energy consumption increases enormously, especially in Asia. The drivers behind the development are population and GDP growth, and prosperity increase." The most intense growth will be witnessed in Asia, especially in China and India, and also in South-America. The development in Europe will be more moderate, and in Finland the energy consumption may even stall in case the energy-intensive industry continues to flee the country. Energy prices are also likely to increase, but not remarkably. The world energy mix will diversify, and the development is going to be most rapid in Europe, which is the leading continent in implementing RE production capacity. Fossil fuels will remain widely in use, and their consumption will even increase in fast developing countries, such as China and India, as well as in the USA that increasingly exploits shale oil and gas from its own soil. Global warming will continue at an increasing rate due to the still increasing use of fossil fuels, and the biggest greenhouse gas (GHG) polluters; China's, India's, and the USA's short term policies do not include participation in the GHG emission reduction schemes. However, the effects of global warming will gradually become so evident that these nations will join the pact eventually. Energy efficiency was considered a very important topic, and the development was estimated to be positive, although the optimisation potential in heat energy was considered higher than in electricity consumption.

Some key informants considered the energy, environmental and financial policies to be tightly interconnected, especially in the EU. One interviewee said: "Energy policy is subordinate to EU's environmental policy. Energy investments should be non-risky investments, and energy production should be reliable, efficient, competitive and environmentally friendly." Another specialist evaluated that the entire global energy ecosystem is in a radical transition phase: "We live in an era of the biggest energy revolution and transition ever witnessed. Centralised utility-based energy systems are being replaced by decentralised energy systems."

Many experts shared the view that onshore wind power and distributed bio-CHP will be competitive without subsidies in 10 to 20 years, while their technologies mature and the effects of the scale of economies can be fully exploited. However, before that subsidies are essential in order to commercialise wind power and bio-energy efficiently. After that, the subsidies should be gradually scaled down. In general, political support schemes are rather predictable and long-term, thus increasing investors' and other players' confidence in RE. Further, grid reinforcements, smart grid development, standby power production capacity, and elec- 
tricity storage issues are all very important in the diffusion of intermittent and decentralized RE. For instance Germany, Denmark and Spain have been very successful in commercialising wind power, and Germany and Austria have succeeded in bio-energy diffusion.

Some informants considered that onshore wind power and distributed bio-CHP are already competitive when the local conditions are favourable, as one informant mentioned: "Onshore wind power is already competitive; when the circumstances are favourable, i.e. the site and wind conditions are fair. Distributed bio-CHP should also be competitive; especially when it competes on consumer markets that exist when the plant produces own electricity to the owner." Subsidies were also seen problematic by some experts: "For instance. Germany and Denmark have been successful in RE diffusion, but what has been the price; generally the consumers are paying a higher price of the electricity because of subsidies. On the other hand, in case there is electricity surplus, it may be dumped to neighbour countries' grids that skew free competition." Other challenges were also identified in commercializing RE in Finland, such as public resistance, bureaucracy, and quite late introduction of support schemes. One key informant concluded: "Although citizens mainly support RE diffusion, not-in-my-backyard issues also exist. This probably takes places because our RE development is behind the development in Europe, where such problems do not exist. For example bureaucracy in land use and the Defence Forces' radar issues create delays and additional costs for wind power." Countries that have innovated and invested into wind power and bio-energy technologies in early stages have benefitted from first-mover advantages, national employment and industrial clusters, otherwise than Finland. One informant continued: "Ger- many and Denmark have benefited from developing and commercializing RE in forms of domestic and international business opportunities, employment, and industrial clusters. Finland has lost the first-mover advantages and cluster opportunities in the wind power business. However, there might still exist opportunities in bio-energy, energy storage and efficiency issues. After all, the development and commercialising of RE is as much environmental and industry policy that benefits the whole nation".

All in all, Europe is the leading continent in RE diffusion that could contribute new innovations, investments in RE, and technological advantages and welfare in the long term. According to the interviewees, it seems evident that the influences of global warming will gradually become evident for most people and nations, and that will probably lead to increasing sanctions for fossil fuels and shutdowns of the most polluting production methods, which will give an additional boost to RE diffusion. Subsidies such as FITs, innovation and investment support schemes to RE, and emission trading schemes for GHG emitters are among the most important drivers for RE diffusion before the industry is mature enough to compete with other energy production methods. In addition, grid investments, energy storage systems, standby energy production, and citizens' support are required in order to ensure smooth $\mathrm{RE}$ diffusion. To conclude, successful RE diffusion needs a wide array of actions and favorable circumstances. The generally and widely shared opinions of the interviewees concerning general energy development and renewable energy development are summarized in table 4. Also specific issues related to general and renewable energy development raised by the experts are summarised in the table.

Table 4. Shared and additional expert opinions about energy development by 2030.

\begin{tabular}{|c|c|}
\hline Description & Development views \\
\hline $\begin{array}{l}\text { Shared general energy } \\
\text { development views }\end{array}$ & $\begin{array}{l}\text { Energy and especially electricity use will increase remarkably globally. The price of electricity will increase more } \\
\text { sharply than the energy prices in general. The main drivers for the development are population and GDP growth. } \\
\text { The fastest growth will take place in developing countries, especially in Asia and South America. The world's } \\
\text { energy mix will diversify and the share of RE increase, especially in Europe. The development of energy } \\
\text { efficiency will be positive. The use of fossil fuels and emissions will continue to grow, especially e.g. in China and } \\
\text { India. The short-term policies of several countries, including the USA, China and India do not involve } \\
\text { participating in GHG emission reduction schemes. During the coming decades, global warming will continue, and } \\
\text { the sustainable level of two degrees will be exceeded. }\end{array}$ \\
\hline $\begin{array}{l}\text { Shared renewable energy } \\
\text { development views }\end{array}$ & $\begin{array}{l}\text { In general, wind power and distributed bio-CHP may be competitive in } 10-20 \text { years without subsidies after the } \\
\text { technology matures, but today support schemes are essential for RE diffusion. Political support schemes are rather } \\
\text { predictable and long-term. Grid reinforcement, smart grid development, standby power production capacity and } \\
\text { electricity storage issues all are very important for intermittent RE diffusion. E.g. Germany, Denmark and Spain } \\
\text { have been successful in wind power diffusion, and Austria and Germany with bio-CHP. }\end{array}$ \\
\hline $\begin{array}{l}\text { Additional general energy } \\
\text { development views }\end{array}$ & $\begin{array}{l}\text { This is the biggest ever witnessed energy revolution and transition from centralized towards distributed energy } \\
\text { systems. In general, the energy policy is subordinate to EU's environmental policy. Long-term energy investments } \\
\text { should be non-risky, providing secure and low-cost energy. Especially in the USA, interest groups are lobbying for } \\
\text { fossil fuels e.g. shale oil and gas. In Finland, citizens and authorities resist wind power diffusion, partly because } \\
\text { we are behind the RE development in the EU. The EU is the global leader in implementing RE. This policy may } \\
\text { hurt Europe's economical competitiveness in the short term, but it may bring new innovations, investments and } \\
\text { technological leadership in RE in the long term. }\end{array}$ \\
\hline $\begin{array}{l}\text { Additional renewable energy } \\
\text { development views }\end{array}$ & $\begin{array}{l}\text { Wind power is already competitive at favorable sites, and the competitiveness of bio-CHP also depends } \\
\text { significantly on local conditions. Wind farms compete in the electricity stock markets, and distributed bio-CHP in } \\
\text { local markets, where plant owners produce electricity for their own use. Political support schemes, especially at } \\
\text { the EU level are not necessarily long-term, transparent and predictable. The subsidies should be reduced when the } \\
\text { RE technologies mature. The risk is that all energy production, including fossil fuels will be subsidized more. }\end{array}$ \\
\hline
\end{tabular}


Consumers pay a higher price because of energy subsidies and sanctions. Some countries, e.g. Germany and Denmark have extensive support schemes that skew free competition. Innovations and investments in RE have created industrial clusters and prosperity in countries such as Germany and Denmark. Finland has lost the industrial opportunities for wind power, but bio-CHP, energy storages and efficiency issues could still offer opportunities. Investment into RE is as much an industrial policy as an environmental issue.

\section{Discussion and Conclusions}

The global climate change and the predicted increase in energy consumption during the next decades have increased the importance of improved overall energy efficiency, as well as accelerated utilisation of renewable energy sources. The world's wind and bio-energy resources are significant, and technologies already exist to harness a considerable proportion of the primary renewable energy sources. However, wind power and distributed small-scale bio-CHP are still in the infancy of their lifecycle, and require various support schemes in order to be competitive alternative energy sources in the world's energy mix.

This qualitative case study focused on issues of how energy subsidies and other support instruments could promote the diffusion of renewable energy in Finland and selected other European countries. The results revealed that $\mathrm{RE}$ is subsidised and supported by varying methods in different countries, but fossil fuels are also subsidised by enormous funding by many nations. The most common support mechanisms are feed-in tariffs and production premiums that guarantee a certain price for the electricity fed into the grid. Some of the key informants also criticised the fact that in some countries the subsidies are too extensive, increasing the consumer prices and skewing free competition. As regards renewable energy innovation and diffusion, the most sustainable growth appears to take place in countries like Denmark and Germany, for example, that implement a predictable, long-term, and broad portfolio of support schemes for renewable energy. Direct energy subsidies and indirect price-based incentives are the most important instruments, but other support forms, such as government or private investments into an adequate energy infrastructure and general public support are equally important for the diffusion of wind power and bio-energy. The biggest hindrances include unpredictable short-term stop-and-go support policies, and uncompetitive emerging technologies. Based on the favorable diffusion of RES in the studied countries, Denmark and Germany, and the key informants' opinions, we can conclude that the most probable future scenario is that the share of RES will increase significantly in countries that implement adequate support schemes. The wide diffusion of wind power and bio-energy paves the way to their competitiveness without subsidies in 10-20 years. The study contributes to earlier research by confirming that a predictable, long-term array of support instruments is necessary for the competitiveness of emerging technologies and ecosystems prior to their technological maturity and the effects of scale of economies, for example.
In order to ensure the validity and reliability of the research, a semi-structured questionnaire was designed and cross-checked by two researches, and the interviewees composed an adequate group of top energy experts. However, there always exists a potential bias in the selection and contribution of the respondents. In the future, the study could be augmented to cover a broader array of respondents, green technologies, and countries in different continents. Quantitative data such as e.g. [48, 49] could also be included in order to more rigorously verify the scientific generalization of the research results.

\section{Acknowledgements}

The authors are very grateful to the distinguished specialists who have contributed to the research significantly.

\section{References}

[1] Smil, V. "Energy transitions - history, requirements, prospects". Santa Barbara: Praeger publishing. 178 p. 2010.

[2] Lynas, M. "Six degrees. Our future on a hotter planet". Washington, D.C: National Geographic. 335 p. 2008.

[3] Tekes. "Growing power. Bioenergy solutions from Finland". Research reports. 43 p. [retrieved August, 2012]. Available from:

$<$ http://www.tekes.fi/fi/community/Etusivu/307/Haku/383?tf _query=growing + power $>$. 2009.

[4] International Energy Agency (IEA). "World energy outlook 2012”. Paris: Corlet. 668 p. 2012.

[5] Shell. "Shell energy scenarios to 2050". [Retrieved November 2012]. Available from< http://www-static.shell.com/static/public/downloads/brochur es/corporate_pkg/scenarios/shell_energy_scenarios_2050.pd f>. 2008 .

[6] Gore, A. "Our choice. A plan to solve the climate crisis". New York: Melcher Media. 414 p. 2009.

[7] Global Wind Energy Council (GWEC). "Global wind report. Annual market update 2011”. [Retrieved September 2012]. Available

fromhttp://gwec.net/wp-content/uploads/2012/06/Annual_re port_2011_lowres.pdf. 2012.

[8] Ruska, M., Kiviluoma, J. "Renewable electricity in Europe. Current state, drivers, and scenarios for 2020". VTT research notes 2584. [Retrieved November 2012]. Available from $<$ http://www.vtt.fi/inf/pdf/tiedotteet/2011/T2584.pdf>. 2011.

[9] Sipilä, K., Mäkinen, T., Wilen, C., Solantausta, Y., Arasto, A., Helynen, S., den Uil, H., Vehlow, J., Schwaiger, H., Gabrielle, 
B., Peck, P., Rogulska, M. \& Luxmore, C. (edit.). "Bioenergy in Europe. Implementation of EU directives and policies relating to bioenergy in Europe and RD\&D priorities for the future". VTT research notes 2441. [Retrieved November 2012]. Available from $<$ http://www.vtt.fi/inf/pdf/tiedotteet/2008/T2441.pdf>. 2008.

[10] European Environment Agency (EEA). "Environmental tax reform in Europe: opportunities for eco-innovation. EEA technical report no 17/2011”. [Retrieved November 2012]. Available from $<$ http://www.eea.europa.eu/publications/environmental-tax-re form-opportunities>. 2011.

[11] Buen, J. "Danish and Norwegian wind industry: The relationship between policy instruments, innovation and diffusion”. Energy Policy, Vol. 34, pp 3887-3897. 2006.

[12] Faaij, A., P., C. "Bio-energy in Europe: changing technology choices”. Energy Policy, Vol. 34, pp. 322-342. 2006.

[13] Global Wind Energy Council (GWEC). "Global wind energy outlook 2008". [Retrieved August 2012]. Available from $<$ http://www.gwec.net/fileadmin/images/Logos/Corporate/G WEO_A4_2008_lowres.pdf $>$. 2008.

[14] European Wind Energy Association (EWEA). "Oceans of opportunity - Harnessing Europe's largest domestic energy resource". [Retrieved August 2012]. Available from $<$ http://www.ewea.org/fileadmin/ewea_documents/documen ts/publications/reports/Offshore_Report_2009.pdf>. 2009.

[15] Sahin, A.D. "Progress and recent trends in wind energy", Progress in Energy and Combustion Science, Vol. 30, pp. 501-543. 2004

[16] Dismukes, J.P., Miller, L.K., Bers, J.A. "The industrial life cycle of wind energy electrical power generation ARI methodology modeling of life cycle dynamics", Technological Forecasting and Social Change, Vol. 76, pp. 178-191. 2009.

[17] Manwell, J., F., McGovan, J., G., Rogers, A., L. "Wind energy explained - Theory, design and application". Second edition. Chichester: John Wiley \& Sons. 689 p. 2010.

[18] BTM Consult ApS. "International wind energy development - Supply chain assessment 2012-2015". [Retrieved August 2012]. Available from $<$ http://www.btm.dk/reports/supply+chain+assessment+2012 $>$, commercial report. 2012a.

[19] BTM Consult ApS. "International wind energy development - World market update 2011". [Retrieved August 2012]. Available from $<$ http://www.btm.dk/reports/world + market+update+201 1>, commercial report. $2012 \mathrm{~b}$.

[20] Kara, M., Hirvonen, R., Mattila, L., Viinikainen, S., Tuhkanen, S. "Energy visions 2030 for Finland". VTT Energy. Helsinki: Edita. 237 p. 2003.

[21] Pehnt, M., Cames, M., Fischer, C., Praetorius, B., Schneider, L., Schumacher, K., Voss, J.-P. „Micro cogeneration - Towards decentralized energy systems”. E-book. 346 p. 2006.

[22] Kokkonen, K., Lehtovaara, M., Rousku, P., Kässi, T. "Networking of biomass heating enterprises - a two-dimensional approach". XX11 ISPIM Conference - Sustainability in Innovation: Innovation Management Challenges. June 12-15 2011. Hamburg. Germany. 2011.
[23] Eurostat. "Key figures on Europe 2012". [Retrieved February 2013]. Available from<http://epp.eurostat.ec.europa.eu/cache/ITY OFFPUB/ KS-EI-12-001/EN/KS-EI-12-001-EN.PDF.>. 2012a.

[24] Eurostat. "Energy, transport and environment indicators". [Retrieved March 2013]. Available from<http://epp.eurostat.ec.europa.eu/cache/ITY_OFFPUB/ KS-DK-12-001/EN/KS-DK-12-001-EN.PDF.> 2012b.

[25] Statistics Finland. [Retrieved March 2013]. Available from<http://www.tilastokeskus.fi/index_en.html.> 2013.

[26] Danish Energy Agency. "Energy statistics 2010". [Retrieved March 2013]. Available from<http://www.ens.dk/en-US/Info/FactsAndFigures/Ener gy_statistics_and_indicators/Annual\%20Statistics/Documen ts/Energy\%20Statistics\%202010.pdf.> 2010.

[27] BMU. Federal Ministry for the Environment, Nature Conservation and Nuclear safety. "Development of renewable energy sources in Germany 2011". [Retrieved March 2013]. Available

from<http://www.erneuerbare-energien.de/fileadmin/ee-imp ort/files/english/pdf/application/pdf/ee_in_deutschland_graf _tab_en.pdf.> 2012.

[28] International Energy Agency (IEA). "World energy outlook 2011”. Paris: Soregraph. 659 p. 2011.

[29] Ernst \& Young. "Renewable energy country attractiveness indices". Issue 31. [Retrieved November 2012]. Available from $<$

http://www.ey.com/Publication/vwLUAssets/Renewable_en er-

gy_country_attractiveness_indices_-_Issue_31/\$FILE/EY RECAI issue 31.pdf $>$. 2011 .

[30] Kamp, L., M., Van der Duin, P., A. "Analysing the wind turbine innovation systems in The Netherlands and Denmark using the cyclic innovation model". Int. J. Engineering Management and Economics, Vol. 2, No 1, pp 39-59. 2011.

[31] Carvalho, M., da G. "EU energy and climate change strategy". Energy, Vol. 40, pp 19-22. 2012.

[32] European Commission (EC). "Renewable energy: a major player in the European energy market". Commission staff working document. [Retrieved November 2012]. Available from $<$ http://ec.europa.eu/energy/observatory/countries/doc/key_fi gures.pdf $>$. 2012

[33] Sovacool, B., K. "The political economy of energy poverty: A review of key challenges". Energy for Sustainable Development, Vol. 16, pp 272-282. 2012.

[34] Trypolska, G. "Feed-in tariff in Ukraine: The only driver of renewables' industry growth?" Energy Policy, Vol. 45, pp 645-653. 2012.

[35] Erturk, M. "The evaluation of feed-in tariff regulation of Turkey for onshore wind energy based on the economic analysis". Energy Policy, Vol. 45, pp 359-367. 2012.

[36] Butler, L., Neuhoff, K. "Comparison of feed-in tariff, quota and auction mechanisms to support wind power development”. Renewable Energy, Vol. 33, pp 1854-1867. 2008.

[37] Laird, F., N., Stefes, C. "The diverging paths of German and United States policies for renewable energy: sources of dif- 
ference”. Energy Policy, Vol. 37, pp 2619-2629. 2009.

[38] Saidur, R., Islam, M., R., Rahim, N., A., Solagi, K., H. “A review on global wind energy policy". Renewable and Sustainable Energy reviews, Vol. 14, pp 1744-1762. 2010.

[39] Moreno, B., Lopez, A., J., Garcia-Alvarez, M., T. "The electricity prices in the European Union. The role of renewable energies and regulatory electric market reforms". Energy, Vol. 48, pp 307-313. 2012.

[40] Jefferson, M. "Accelerating the transition to sustainable energy systems". Energy policy, Vol. 36, pp 4116-4125. 2008.

[41] Van der Hoeven, M. "IEA vision on international energy governance". Energy Strategy Reviews, Vol. 1, pp 73-75. 2012.

[42] Kohl, J., Loikkanen, T., Hernesniemi, H., Simons, M., Koljonen, T., Nikulainen, T., Valovirta, V., Talja, H., Similä, L. "Prospects for Finland's opportunities in global renewable energy business. Näkymiä Suomen mahdollisuuksista uusiutuvaan energiaan liittyvässä globaalissa liiketoiminnassa" (in Finnish). Ministry of Employment and the Economy Publications, Competitiveness 24/2012. Edita Publishing. 214 p. 2012.

[43] Danish Energy Agency. [Retrieved February 2013]. Available from $<$ http://www.ens.dk/en-US/Sider/forside.aspx $>$. 2013.
[44] BMU. Federal Ministry for the Environment, Nature Conservation and Nuclear Safety. "Tariffs, degression and sample calculations pursuant to the new Renewable Energy Sources Act (EEG 2012)". [Retrieved February 2013]. Available from<http://www.erneuerbare-energien.de/fileadmin/ee-imp ort/files/english/pdf/application/pdf/eeg_2012_verguetungsd egression_en_bf.pdf. 2013.

[45] Yin, R.K. "Case study research. Design and methods". 4th edition. USA: SAGE Publications. 224 p. 2009.

[46] Eisenhardt, K. "Building theories from case study research". Academy of Management review, Vol. 14, No 4, pp 532-550. 1989.

[47] Creswell, J., W. "Qualitative inquiry \& research design. Choosing among five approaches". 2nd edition. USA: SAGE Publications. 395 p. 2007.

[48] Johnstone, N., Hascic, I., Popp, D. "Renewable energy policies and technological innovation: evidence based on patent counts". Environ Resource Econ, Vol. 45, pp 135-155. 2010 .

[49] Popp, D., Hascic, I., Medhi, N. "Technology and diffusion of renewable energy”. Energy Economics, Vol. 33, pp 648-662. 2011. 